\title{
PERAN AUDIT INTERNAL TERHADAP KEPATUHAN PERANGKAT DAERAH DALAM PENGELOLAAN KEUANGAN PADA KANTOR INSPEKTORAT DAERAH PROVINSI SULAWESI UTARA
}

\author{
Thalia Amelia Constantie Rambing ${ }^{1}$, Jantje J. Tinangon ${ }^{2}$, Winston Pontoh ${ }^{3}$ \\ ${ }^{1,2,3}$ Fakultas Ekonomi dan Bisnis, Jurusan Akuntansi, Universitas Sam Ratulangi, Jl. Kampus Bahu, Manado, \\ 95115, Indonesia \\ E-mail : constntietr@gmail.com
}

\begin{abstract}
Internal audit is an activity carried out independently, objectively believes in its examination, and conducts consultations in management with the aim of increasing the value and performance of the organization. The role of internal audit which is APIP (Government Internal Supervisory Apparatus) plays an important role in the government system, namely as a function of controlling where APIP is given responsibility in evaluating and evaluating and carrying out management functions, namely planning, organizing functions, directing function and coordinating function. The purpose of the study was to determine the role of internal audits on the compliance of regional devices in financial management and how APIP is independent in carrying out supervision and inspection. The method used in this study is a descriptive method that is by collecting data from the results of the study and then analyzing and drawing conclusions from the research. The results of the study obtained that the North Sulawesi Province Inspectorate was very instrumental in overseeing the financial management of regional equipment. This is evidenced by the implementation of its functions in the Internal Audit as the Government Internal Control Apparatus (APIP) which oversees and oversees the planning, organizing, directing and coordinating of financial management by SKPD in North Sulawesi.
\end{abstract}

Keywords: Internal Audit, Role of Audit, Independent

\section{PENDAHULUAN}

Dalam pengolaan Negara, pemerintah membutuhkan dana yang besar dalam penataan dan pembangunan Negara. Dana harus didistribusikan secara merata dan adil sesuai dengan kebutuhan tiap sektor publik sehingga penggunaan dana dapat dipertanggungjawabkan. Karenanya dibutuhkan pengelolaan dan pengawasan dalam menjalankan pemerintahan untuk memperoleh pertanggungjawaban yang efektif dan efisien. Dalam meminimalisir akibat atau resiko tuntutan hukum terhadap aparatur pemerintah dalam penyimpangan penggunaan anggaran, dibutuhkan audit sektor publik yang berkualitas dalam pengawasan keuangan pemerintah.

Elder, Beasle, dan Arens (2015:41) mengatakan proses auditing merupakan proses dimana auditor mengumpulkan dan mengevaluasi semua informasi dan juga bukri-bukti yang ditemui dan dapat menjadikan entitas ekonomi menjadi lebih kompeten dan independan dalam menentukan dan melaksanakan pelaporan indformasi yang telah didapat sesuai dengan aturan-aturannya. Oleh karena itu dibutuhkan seorang yang mampu bertindak berdasarkan prosedur serta tidak terpengaruh oleh pihak lain untuk bertindak jujur dan benar dalam menjalankan pengawasan dan pemeriksaan di lapangan. Seorang auditor harus memiliki kualitas yang baik agar dapat dipercaya dalam pengambilan suatu keputusan.

Dalam pelaksanaan audit, auditor yang ditugaskan harus mampu melaksanakan tugasnya dengan independen dan tanpa melakukan pertimbangan-pertimbangan terhadap objeknya. Tanpa sikap independen auditor akan sulit untuk menentukan hasil sesuai dengan 
kenyataan yang terjadi dan dapat berpengaruh terhadap kualitas audit itu sendiri dalam penetapan keputusan.

\section{TINJAUAN PUSTAKA}

Internal Audit. Boynton, Johnson, dan Kell (2007:15) mengatakan bahwa audit merupakan sebuah proses yang dilakukan secara sistematis yang bertujuan menetapkan tingkat kesesuaian antara pelaksanaan dengan aturan yang telah diatur dan juga untuk menyampaikan hasil untuk pihak yang memiliki kepentingan dalam memperoleh dan mengevaluasi bukti secara objektif mengenai asersi-asersi kegiatan dan peristiwa ekonomi. Hal yang sama juga yang dikutip dalam buku yang berjudul Auditing and Assurance Services yang dikutip dalam Messier, Glover, dan Prawitt (2014:21) mendefinisikan audit internal merupakan suatu kegiatan yang dilakukan dengan independen, berkeyakinan objektif dalam pemeriksaannya, dan melakukan konsultasi dalam manajemen dengan tujuan agar dapat menaikan nilai dan kirerja dalam organisasi.

Jenis-Jenis Audit. Boynton et al. (2007:24) mengatakan bahwa jenis audit terbagi atas:

1. Financial Audit atau Audit Laporan Keuangan yang dilaksanakan agar supaya informasi dalam laporan keuangan dapat dipastikan adalah terstruktur dan dibuat dengan benar menjalankan kriteria yang telah ditetapkan.

2. Compliance Audit atau Audit Ketaatan merupakan kegiatan yang dilakukan auditor dengan tujuan untuk mengetahui auditee atau klien yang diaudit sudah melaksanakan pengorganisasian dengan berdasarkan prosedur dan peraturan yang diatur pihak yang mempunyai otoritas tertinggi.

3. Operational Audit atau Audit Operasional merupakan audit dalam menilai efisiensi dan keefektifitas dalam pengauditannya dengan menelaah setiap prosedur ataupun metode operasi didalam manajemen yang biasanya disertai dengan pemberian saran terhadap organisasi manajemen untuk menjalakan operasi dengan baik.

Tanggung Jawab Dan Fungsi dari Audit Internal. Kurniawan (2012:31) mengemukakan bahwa fungsi audit internal yaitu untuk memberikan jasa untuk manajemen di organisasi baik dalam audit operasional maupun didalam audit kinerja dengan harapan bisa menolong pemantauan kerja dari karyawan yang dikerjakan didalam oganisasi tentunya oleh para kepala manajemen dan dewan-dewan didalamnya. Tunggal (2014:42) menyebutkan bahwa tanggung jawab auditor internal yaitu:

1. Direktur audit internal bertanggung jawab dalam penerapan program internal audit, berperan dalam pengarahan angota indternal audit dan segala kegiatannya, menyusun program di tiap periode dalam menjalakan pemeriksaan disemua unit organisasi serta membuat program untuk disetujui.

2. Auditing Superior memiliki tanggungjawab dalam membantu direktur audit internal untuk mengembangkan dan mengkoordiasikan segala program yang telah disusun dan direncanakan oleh direktur audit tiap periodenya.

3. Tanggung jawab dari senior auditing adalah mengikuti semua program audit yang telah disusun dan melaksanakan semua instruksi dan tugas dalam area audit mulai dari supervisor audit dan memimpin staf dalam pekerjaan lapangan.

Perbedaan Antara Audit Internal dan Eksternal. Menurut Hery (2017:52) terdapat perbedaan antara audit internal dan audit eksternal yaitu:

1. Internal audit dilaksanakan oleh pihak yang berasal dari dalam perusahaan sedangkan eksternal audit dilaksanakan oleh pihak yang bukan dari dalam perusahaan.

2. Audit internal sering disebut tidak independen oleh pihak luar organisasi sedangkan audit eksternal merupakan pihak yang bersifat independen. 
3. Audit internal bertugas dalam memberikan penilaian, analisis dan juga saran. Sedangkan audit eksternal bertugas dalam pemberian opini dan pendapat.

4. Audit internal memuat temuan tentang penyimpangan yang dilakukan oleh pihak dalam organisasi, dan kecurang yang terjadi. Sedangkan audit eksternal memuat opini auditor tentang laporan keuangan yang diperiksa dengan indikasi wajar atau tidak wajar.

5. Berpedoman pada standar oleh Institute of Internal Auditors yaitu Internal Auditing Standard dan dalam lingkungan BUMN/BUMD digunakan Norma Pemeriksaan Internal oleh BPKP oleh BPKP. Dan audit ekseternal menggunakan pedoman sesuai penetapan Institut Akuntan Publik Indonesia (IAPI) yaitu Standar Profesional Akuntan Publik (SPAP).

6. Kegiatan pemeriksaan audit internal memiliki waktu lebih banyak dari pada audit eksternal dalam melakukan pemeriksaan didalam organisasi.

7. Pemeriksaan audit internal tidak harus dipimpin oleh akuntan yang terdaftar dan memiliki nomor register (registreted accountant) sedangkan eksternal audit harus.

8. Didalam pemeriksaan audit internal tidak membutuhkan surat perwakilan klien sedangkan pada audit eksternal harus terlebih dahulu di mintai surat perwakilan tersebut

Tahapan Audit Internal. Tunggal (2014:39) mengatakan bahwa ada lima proses yang menjadi tahapan audit internal sesuai dengan pelaksanaannya. Yang pertama adalah audit planning and risk analysis yang merupakan tahapan proses audit yang perencanaannya difokuskan dengan mempertimbangkan apa, dimana, dan kapan dilakukan.

Peraturan Perundang-undangan Mengenai Audit Internal. Yang menjadi acuan hukum untuk penyusunan dan pelaksanaan teknis didalam mereviu laporan keuangan adalah sebagai berikut:

1. UU RI No. 17 Tahun 2003 tentang Keuangan Negara,

2. UU RI N0. 1 Tahun 2004 tentang Perbendaharaan Negara,

3. UU RI No. 15 Tahun 2004 tentang Pemeriksaan Pengelolaan dan Tanggung Jawab Keuangan Negara,

4. PP RI No. 24 Tahun 2005 tentang Standar Akuntansi Pemerintahan;

5. PP RI No. 6 Tahun 2006 tentang Pengelolaan Barang Milik Negara/Daerah;

6. PP RI No. 8 Tahun 2006 tentang Pelaporan Keuangan dan Kinerja Instansi Pemerintah,

7. PP RI No. 60 Tahun 2008 tentang Sitem Pengendalian Intern Pemeritah.

8. Permendagri No. 4 tahun 2008 tentang Pedoman Pelaksanaan Review atas Laporan keuangan Pemerintah Daerah.

Profesionalisme Auditor Internal. Menurut Wokas dan Karamoy (2015) mengatakan bahwa dalam pendeteksian kecurangan dan penyimpangan yang terjadi dapat dipengaruhi tentang profesionalitas seorang auditor. Sawyer (2012:16) menyatakan bahwa seorang auditor internal diakui bahwa dia adalah seorang audit yang profesional ketika telah mempunyai sikap independen dalam menyanggupi keharusan dalam profesinya baik dalam pemberikan opini yang objektif, tidak bias, dan tidak dibatasi juga dalam memberi laporan sesua dengan yang terjadi bukan dengan laporan yang di arahkan dengan mementingkan kepentingan eksekutif maupun lembaga yang bersangkutan. Wokas, Ilat, dan Saerang (2015) yang didalam penelitiannya menyebutkan bahwa Independensi dapat mempengaruhi kualitas audit dan ternyata menunjukan bahwa independen tidak berpengaruh signifikan terhadap kualitas audit pada auditor internal.

Teori Peran. Menurut Kozier dikutip dalam Lia (2011:19) menyatakan bahwa peran merupakan bentuk dari perilaku yang diharapkan dari seesorang pada situasi sosial tertentu. Dikatakan Levinson yang dikutip dalam Soekanto (2012:20) menyatakan bahwa peranan meliputi tiga hal, yaitu: 
1. Meliputi aturan yang berhubungan dengan posisi atau kedudukan seseorang dalam bermasyarakat. Dalam artianya peran ini merupakan rangkaian aturan yang menuntun seorang di dalam menjalankan kehidupan dalam masyarakat.

2. Adalah konsep mengenai apa yang dapat dilakukan individu didalam berorganisasi dan bersosialisasi di masyarakat.

3. Merupakan pentingnya perilaku individu yang dapat mempengaruhi struktur sosial dalam bermasyarakat.

Penelitian Terdahulu. Gita (2015) dengan judul mengulik peran auditor internal dalam melakukan deteksi dan pencegahan fraud di perguruan tinggi. Hasil penelitian mengatakan bahwa audit internal sudah melaksanakan pendeteksian dan pencegahan kecurangan di dalam kegiatan-kegiatan yang dilaksanakannya. Pengawasan yang dilakukan terbukti banyak mencegah kerugian yang terjadi akibat dari kecurangan. Lucy (2013) dengan judul peranan audit internal dalam mencegah dan mendeteksi kecurangan(fraud). Hasil penelitian ini menunjukan bahwa kontrol internal sebenarnya berperan dalam pelaksanaan managemen. Dibuktikan dengan kelemahan yang terjadi dalam kontrol internal pada objeknya mengakibatkan stok barang dan laporannya tidak sesuai. Karenanya selisih barang terjadi secara trus menerus.

\section{METODE PENELITIAN}

Jenis Penelitian. Penelitian yang dilakukan ini memakai metode penelitian kualitatif. Menurut Sugiono (2015:14), metode penelitian kualitatif merupakan metode yang dilandasi dengan filsafat positivisme, yang dipakai dalam penelitian dengan situasi objek sebagai percobaan. Dimana peneliti dianggap sebagai pemegang kunci dan sampel dan data diambil dengan menggunakan purposive dan snowball. Kemudian dalam teknik pengumpulan datanya dilakukan tringulasi analisis datanya berbentuk induktif atau kualitatif. Dan hasil yang di dapat menunjukan makna dari pada generalisasi.

Tempat dan Waktu Penelitian. Tempat penelitian dilakukan pada kantor Inspektorat Daerah Provinsi Sulawesi Utara yang beralamat di jalan 17. Agustus, Teling Atas, Kecamatan Wanea Kota Manado. Letaknya di samping kiri kantor Gubernur Sulawesi Utara. Waktu penyusunan penelitian ini dilakukan pada tahun 2018 dari bulan Maret sampai selesai.

\section{Jenis, Sumber dan Metode Pengumpulan data}

Jenis Data. Jenis data yang digunakan dalam penelitian ini adalah jenis data kualitatif yang bersifat deskriptif. Data ini berupa pemaparan uraian kata dan tidak diukur dalam skala numerik.

Sumber data. Penelitian ini dilakukan dengan menggunakan sumber data primer. Data primer adalah data yang diberikan secara langsung yang diperoleh dari objek penelitian dan diberikan kepada peneliti (Sugiyono, 2015:28).

Metode Pengumpulan Data. Metode pengumpulan data yang digunakan adalah:

1. Observasi. Pengempulan bukti melalui pengamatan, pada saat terjadinya aktivitas seseorang, jalannya suatu mekanisme, dan kejadian disekitarnya.

2. Wawancara. Peneliti mewawancarai langsung pihak-pihak yang terkait mengenai data yang diperlukan.

Metode Analisis. Sesuai dengan data yang digunakan yaitu data kualitatif, metode yang digunakan yaitu menganalisis data dilakukan dengan cara menyusun hasil pengamatan secara sistematis sehingga bisa mendapatkan data deskripsi yang baik. Penganalisisan data secara kualitatif terbagi menjadi dua yakni analisis selama pengumpulan data dan analisis setelah maa pengumpulan data. 


\section{HASIL PENELITIAN DAN PEMBAHASAN}

\subsection{Hasil Penelitian}

Peranan Inspektorat Sulawesi Utara Sebagai APIP (Aparat Pengawas Intern

Pemerintah). APIP (Aparat Pengawasan Intern Pemerintah) sangat berperan penting dalam sistem pemerintah yaitu sebagai fungsi pengawasan (controlling) dimana APIP diberikan tanggung jawab didalam mengevaluasi dan penilaian fungsi-fungsi manajemen agar supaya tujuan dari organisasi dapat tercapai. Adapun fungsi manajemen tersebut yaitu fungsi perencanaan (planning), fungsi pengorganisasian (organizing), fungsi pengarahan (directing) dan fungsi koordinasi (coordinating). Dalam makna yang baru, pengawasan internal (APIP) bukan hanya melaksanakan pengawasan dalam pemerintah apakah telah melaksanakan tugas dengan benar sesuai yang telah di atur dan ditetapkan dan melaksanakan pengelolaan keuangan dalam pembelanjaan uang yang seharusnya sesuai dengan yang di perintahkan dan di rencanakan dan juga taat terhadap peraturan perundang-undangan yang telah diberlakukan (oversight), juga APIP turut memberi konsultasi untuk mempertinggi kinerja pemerintan (insight) serta mampu menghadapi tantangan-tantangan dan perkembangan yang akan terjadi dan akan dihadapi pemerintah kedepan (foresight).

Tugas Dari APIP Inspektorat Daerah Provinsi Sulawesi Utara. Tugas dari APIP Inspektorat Daerah telah dijelaskan dalam Tupoksi Inspektorat Daerah sesuai dengan Peraturan Gubernur Provinsi Sulawesi Utara No. 63 Tahun 2008 tentang uraian Tugas Inspektorat Provinsi Sulawesi Utara. Adapun tugas pokok Inspektorat yaitu menolong Gubernur untuk melaksanakan pengawasan di dalam pemerintah melaksanakan urusanurusan pemerintahan daerah baik di daerah provinsi maupun di daerah kabupaten/kota juga pengawasan terhadap pelaksanaan pembinaan atas penyelenggaraan pemerintahan daerah di kabupaten/kota. Inspektorat melaksanakan fungsinya yakni:

1. Merencanakan program pengawasan

2. Merumuskan kebijakan dan fasilitas pengawasan

3. Memeriksaan, mengusut, menguji, dan menilai tugas pengawasan

4. Memberikan dukungan atas penyelenggaraan pemerintahan daerah dibidang pengawasan

5. Menyelenggarakan urusan administrasi kesekretariatan

6. Melaksanakan tugas lain yang diberikan oleh Gubernur.

Tata Kerja Kelompok Jabatan Fungsional Pada Inspekorat. Menurut Permenpan 220/2008 Pasal 7 tentang Jabatan Fungsional Auditor bab 5 mengenai Jenjang Jabatan Dan Pangkat.

1. Jabatan Fungsional Auditor sebagai berikut: (a) Auditor Terampil; dan (b) Auditor Ahli.

2. Jenjang Jabatan Fungsional Auditor Ahli adalah sebagai berikut: (a) Auditor Utama; (b) Auditor Madya; (c) Auditor Muda; dan (d) Auditor Pertama.

3. Jenjang Jabatan Fungsional Auditor Terampil sebagai berikut: (a) Auditor Penyelia; (b) Auditor Pelaksana; dan (c) Auditor Pelaksana Lanjutan.

\subsection{Pembahasan}

Analisis Peran Inspektorat Sulawesi Utara Sebagai APIP (Aparat Pengawas Internal Pemerintah). Sesuai dengan Permendagri No. 64 Tahun 2007, pemerintah sudah menetapkan kebijakan-kebijakan yang merupakan tugas dan fungsi dari Inspektorat. Ada beberapa kebijakan yang harus dijalankan oleh Inspektorat Daerah Provinsi Sulawesi Utara dalam pengimplementasian kebijakan untuk mendukung terselenggaranya kegiatan pengawasan yang efektif yang merupakan faktor utama yang sangat penting untuk diperhatikan oleh Inspektorat Daerah sebagai pelaksana pengawasan pemerintah daerah. Adapun yang telah dilaksanakan Inspektorat Daerah Provinsi Sulawesi Utara sebagai 
pengawas internal dalam pengimplementasian kebijakan-kebijakan yang memuat fungsi sesuai peraturan yang telah ditetapkan diantaranya:

1. Merencanakan program pengawasan. Inspektorat Daerah Sulawesi Utara melaksanakan perencanaan pengawasan diantaranya:

- Pelaksanaan Musrenbang

- Penyusunan Renja (Rencana Kerja) SKPD

- Penyusunan RKA (Rencana Kerja Anggaran)

- Menyerahkan RKA ke TAPD (Tim Anggaran Pemerintah Daerah) untuk ditelaah kesesuaiannya dan bersama dengan RKA SKPD lain dijadikan acuan sebagai bagian penyusunan Raperda APBD.

- Setelah APBD disahkan maka bagian keuangan Inspektorat menyusun DPA sesuai dengan penjabaran APBD. DPA ini merupakan dokumen resmi untuk melaksanakan kegiatan selama satu tahun termasuk kegiatan pengawasan tahunan (pemeriksaan reguler).

2. Merumuskan Kebijakan dan Fasilitas Pengawasan. Inspektorat Daerah Provinsi Sulawesi Utara melaksanakan fungsi Perumusan Kebijakan dan Fasilitasi Pengawasan. Dalam penetapan kebijakan pengawasan selalu memusatkan pedoman dalam kebijakankebijakan sesuai dengan kepentinga daerah baik agar menghindari keadaan tumpang tindih di dalam melaksanakan pengawasan dengan singkron dilakukan dari pemerintah pusat kemudian menuju pada pemerintah provinsi dan kemudian pada pemerintah di daerah. Hasil evaluasi dalam melaksanakan rumusan kebijakan ini menjadikan acuan dalam pengembangan setiap tahun agar kebijakan yang telah disusun telah berjalan sesuai dengan keinginan dan yang diharapkan.

3. Memeriksa, mengusut, menguji dan menilai tugas pengawasan. Memeriksa, mengusut, menguji dan menilai tugas di dalam melaksanakan pengawasan yang dilakukan oleh Inspektorat Daerah Provinsi Sulawesi Utara dilaksanakan dengan melakukan kegiatan diantaranya dalam pemeriksaan keuangan secara reguler dan tematik. Kemudian dilakukan monitoring serta evaluasi di dalam pelaksanaan kegiatan dan kinerja. Selanjutnya mereviu laporan seperti RKA, LAKIP dan LKPD. Dan terakhir melaksanakan tindak lanjut terhadap temuan yang didapat kepada BPK.

Upaya dan Kinerja Inspektorat Sulawesi Utara. Dengan adanya temuan-temuan Inspektorat Provinsi Sulawesi Utara turut berkontribusi dalam pendeteksian dan pengungkapan sehingga temuan tersebut dapat di tindaklanjuti dengan harapan mampu meningkatkan kesadaran SKPD agar supaya tidak terjadi kecurangan yang sama pada periode-periode selanjutnya. Selaku audit internal Inspektorat Sulut melakukan pendeteksian kecurangan dengan memperhatikan indikasi-indikasi kemungkinan terjadinya penyimpangan karena pada dasarnya kecurangan tidak mudah ditemukan. Bukan hanya dengan menemukan indikasi-indikasi terhadap kecurangan, tetapi juga dapat ditemukan dengan adanya informan dari dalam manajemen. Itulah yang biasa disebut dengan whistleblower. Itulah yang menjadi salah satu upaya Ispektorat Sulut yakni dengan menemukas whistleblower dalam objek pemeriksaannya.

Independensi Inspektorat Sebagai Aparatur Pengawasan Internal Pemerintah APIP di Sulawesi Utara. Indikator-indikator untuk mewujudkan independensi didalam menjalankan fungsi pengawasan inspektorat dapat dibagi menjadi beberapa kategori berikut ini:

1. Independensi dalam pengujian audit:

- Pelaksanaan audit dilaksanakan dengan kerja sama antar seluruh perangkat daerah.

- Melaksanakan audit sesuai dengan aturan yang ditetapkan dan tidak tertarik melaksanakan arahan dari pihak tertentu sesuai dengan keinginan dan kepentingannya serta melaksanakan prosedur dalam penetapan bukti yang diterima. 
- Melaksanakan pengawasan dan penugasan dalam audit dengan tidak mengikuti kepentingan dari pihak yang di audit dan tidak melaksanakan pembatasan pengujian audit.

- Bebas melakukan akses ke seluruh catatan, kekayaan, dan pegaia yaitu relevan dengan penugasan auditnya.

2. Independensi pelaporan hasil pengawasan:

- Terlepas dari tekanan dalam enggan mencampurkan masalah yang signifikan didalam laporan hasil audit.

- Terlepas dari segala macam daya yang diperuntukan dalam pelanggaran sebagai auditor yang andal.

- Terbebas dalam emosi yang mengharuskan untuk melakukan perubahan terhadap fakta yang harus dilaporkan.

3. Independensi dalam program kerja pengawasan. Terlepas dari pengaruh penyusunan program kerja pengawasan yang melawan kebijakan dan aturan dalam proses audit.

Sesuai dengan prinsip audit seorang auditor Inspektorat harus memiliki sikap yang tidak memihak dan menghindarikan diri dari kemungkinan terjadinya konflik kepentingan pada dirinya. Obyektivitas seorang auditor profesional harus melekat di dalam dirinya. Obyektivitas merupakan suatu sikap mental yang independen setiap auditor, yang harus selalu tetap dijaganya dalam pelaksanaan penugasan auditnya. Obyektivitas mensyaratkan bagi auditor untuk melaksanakan pekerjaan penugasan audit dengan cara di mana dia memiliki keyakinan yang sejujurnya dalam pelaksanaan pekerjaan audit dan tidak kompromi terhadap kualitas keputusan yang dibuatnya. Auditor tidak boleh ditempatkan pada suatu situasi di mana auditor tersebut tidak merasa cukup aman untuk membuat suatu keputusan atau judgment yang obyektif berkaitan dengan penugasan audit yang dilakukannya.

Manfaat Audit Internal Inspektorat Daerah Provinsi Sulawesi Utara. Manfaat audit internal terhadap pihak yang menjadi objek audit, yaitu untuk memperluas kredibilitas laporan keuangan agar dapat lebih dipercaya dalam meyakinkan pihak ketiga atau pihak luar entitas dalam pelaksanaan kepentingan. Kemudian dalam meminimalisir kelasahan bahkan penyimpangan yang dilakukan didalam catatan keuangan sehingga menghasilkan dasar yang dapat dipercayai.

\section{KESIMPULAN DAN SARAN}

\subsection{Kesimpulan}

Berdasarkan hasil penelitian dan pembahasan sebelumnya, maka dapat ditarik kesimpulan sebagai berikut:

1. Inspektorat Provinsi Sulawesi Utara sangat berperan dalam pengawasan pengelolaan keuangan perangkat daerah. Hal ini dibuktikan dengan pelaksanaan fungsinya dalam Audit Internal sebagai Aparatur Pengawasan Intern Pemerintah (APIP) yang mengawasi dan mengawal jalannya perencanaan, pengorganisasian, pengarahan dan pengkoordinasian pengelolaan keuangan oleh SKPD di Sulawesi Utara. Inspektorat Sulawesi Utara tidak hanya berperan sebagai pengawas tetapi juga berfungsi sebagai penjamin mutu (assurance) yang menjamin kualitas dan konsultasi (consulting) yang memudahkan SKPD jika mendapatkan kendala dalam pengelolaan keuangan. Inspektorat Sulawesi Utara juga memiliki peran dalam pemberlakuan early morning system atau peringatan dini kepada perangkat daerah. Yang dimana APIP melakukan probity audit dengan memeriksa di awal sejak penyusunan rencananya pengadaan. Jadi selain mengawal dan memeriksa APIP juga memiliki peran sebagai pencegahan penyimpangan dalam pengelolaan keuangan SKPD sebagai tugas pokok dan fungsi Inspektorat dalam pembinaan dan penyelenggaraan pemerintahan daerah. 
2. Inspektorat Daerah dalam menjaga Independensinya melaksanakan penyusunan dan penataan penugasan audit dengan memperhatikan keterkaitan antara objek dan auditor untuk menghindari kemungkinan terjadinya konflik kepentingan. Karenanya Inspektur atau kepala Inspektorat secara periodik melakukan reviuw hasil pekerjaan audit untuk memastikan kegiatan audit telah dilaksanakan secara objektif. Kemudian dilakukan rotasi penugasan bagi staf audit. Ketika terjadi konflik kepentingan atau objektivitas yang terganggu, auditor diharuskan untuk melaporkan kepada pimpinan auditnya. Auditor juga dapat meminta untuk dipindahkan atau digantikan tugasnya dalam pemeriksaan ketika memang terjadi konflik kepentingan.

\subsection{Saran}

Pentingnya peningkatan kualitas dan kuantitas aparatur Inspektorat Sulawesi Utara dalam perluasan dan peningkatan kinerja agar lebih efektif dalam pelaksanaan pengawasan. Meningkatkan kapasitas dari inspektorat dapat dengan melakukan perekrutan aparatur dengan pemenuhan syarat sebagai auditor yang harus memiliki kompetensi yang baik. Kegiatan itu dapat memberikan jaminan byang baik dalam kapabiitas pegawai dan juga untuk pimpinan. Tidak hanya itu, inspektorat juga dapa melatih dan membina auditor dalam menerapkan disiplin kerja dengan meningkatkan pengetahuan dalam melaksanakan dan menyelenggarakan pemerintahan dengan melaksanakan sosialisasi bagi para aparatur pemerintah.

Perlunya suatu kebijakan dalam hal penguatan keberadaan dari Inspektorat Daerah dalam pelaksanaan tugas dalam pengawasan, dimana kedudukannya yang berada dalam sub ordinat dari pimpinan tertinggi instansi seperti mentri, gubernur, bupati dan juga walikota yang mengharuskan inspektorat menjalankan kinerjanya belum secara profesional dan independen. Diperlukan suatu unit baru dibawah pimpinan tertinggi yang bertanggung jawab langsung kepada Presiden yang dipercaya mampu menciptakan pengawasan yang lebih objektif. Untuk menindaklanjuti dan dapat segera menyelesaikan rekomendasi hasil pengawasan baik rekomendasi temuan aparat pengawas fungsional (pemerintah/ intern dan ekstern) maka perlu dilakukannya koordinasi dengan Satuan Kerja Perangkat daerah SKPD dan penanganan secara terus-menerus dengan menunjuk petugas/unit untuk menangani masalah penyelewengan tersebut. Meningkatkan pembinaan Pegawai Negeri Sipil (PNS) secara berkala sehingga tidak ada lagi kasus-kasus yang melibatkan PNS. Selain itu, sosialisasi akan bahaya laten korupsi penting dilakukan ke seluruh lapisan masyarakat, sehingga pemerintah dan masyarakat dapat saling bekerjasama untuk mewujudkan good government dan clean government.

\section{DAFTAR PUSTAKA}

Gita. 2015. Mengulik Peran Auditor Internal Dalam Melakukan Deteksi Dan Pencegahan Fraud Di Perguruan Tinggi. Jurnal Bisnis dan Akuntansi Vol. 11, No. 1: 1-16.

Hutami, G. 2014. Pengaruh Konflik Peran dan Ambiguiutas Peran Terhadap Komitmen Independensi Auditor Internal Pemerintah Daerah. Universitas Diponegoro. Semarang.

Hery. 2017. Auditing dan Asurans. Grasindo. Jakarta.

Ikatan Akuntan Publik Indonesia. 2013. Standar Audit (SA) 240. Salemba Empat. Jakarta.

Kurniawan, A. 2012. Audit Internal: Nilai Tambah Bagi Organisasi. Edisi pertama. Yogyakarta.

Peraturan Pemerintah No 8 Tahun 2006 Tentang Pelaporan Keuangan dan Kinerja Instansi Pemerintah. 3 April 2006. Jakarta.

Sugiyono. 2014. Metode Penelitian Pendidikan Pendekatan Kuantitatif, Kualitatif, dan R\&D. Alfabeta. Bandung. 
Sukrisno, A. 2012. Auditing: Petunjuk Praktis Pemeriksaan Akuntan oleh Akuntan Publik. Edisi keempat. Salemba Empat. Jakarta. 2014. Auditing: Pemeriksaan Akuntan. Edisi Ketiga. Salemba Empat. Jakarta.

Syilvi. 2013. Analisis Peran Audit Internal Dalam Mendeteksi Kecurangan Pada Pemerintah Provinsi Sulawesi. Selatan. Skripsi. Universitas Hasanudin. Makassar.

Theresa, Andreas, dan Riska. 2014. Pengaruh Peran Audit Internal Terhadap Pencegahan Kecurangan (Studi Empiris Pada Perbankan Pekanbaru). JOM Fekon Vol. 1, No. 2: 116.

Tunggal, A. W. 2015. Internal Auditing. Edisi lima. Yogyakarta.

Wokas, H., dan Karamoy, H. 2015. Pengaruh Independensi Dan Profesionalisme Dalam Mendeteksi Fraud Pada Auditor Internal Provinsi Sulawesi Utara. Jurnal Riset $\begin{array}{lllll}\text { Akuntansi dan } & \text { Auditing } & \text { Goodwill, } & \end{array}$ https://ejournal.unsrat.ac.id/index.php/goodwill/article/view/10492/10080

Wokas, H., Ilat, V., dan Saerang D. P. E. 2015. Pengaruh Independensi, Obyektifitas, Pengalaman Kerja, Pengetahuan, Serta Integritas Auditor Terhadap Kualitas Hasil Audit Di Lingkungan Pemerintah Daerah Provinsi Sulawesi Utara. Jurnal Riset $\begin{array}{lllll}\text { Akuntansi dan Auditing } & \end{array}$ https://ejournal.unsrat.ac.id/index.php/goodwill/article/view/10492/10080 